This is a self-archived version of an original article. This version may differ from the original in pagination and typographic details.

Author(s): Paldanius, Hilkka

Title: Pohdintaa, selostamista ja tulkintaa : historian esseen tekstilaji tiedonalan tekstitaitojen näkökulmasta

Year: 2020

Version: Published version

Copyright: (c) 2020 Kotikielen seura

Rights: In Copyright

Rights url: http://rightsstatements.org/page/lnc/1.0/?language=en

Please cite the original version:

Paldanius, H. (2020). Pohdintaa, selostamista ja tulkintaa : historian esseen tekstilaji tiedonalan tekstitaitojen näkökulmasta. Virittäjä, 124(4). https://doi.org/10.23982/vir.98382 


\title{
Pohdintaa, selostamista ja tulkintaa
}

\author{
Historian esseen tekstilaji \\ tiedonalan tekstitaitojen näkökulmasta
}

\author{
Hilkka Paldanius
}

\section{Väitöksenalkajaisesitelmä Jyväskylän yliopistossa 5. syyskuuta 2020}

Lukiolainen kirjoittaa koulupäivänsä aikana monenlaisia tekstejä. Tekstien muoto ja kielen piirteet riippuvat siitä, mitä teksteillä halutaan tehdä. Oppitunneilla kirjoitettavat tekstit eroavat usein niistä teksteistä, joita kirjoitetaan luokkahuoneen ulkopuolella, ja siksi opiskelun tekstit ovat myös tutkimusten mukaan sellaisia, joiden tuottamista ei useinkaan opita ilman harjoittelua (Schleppegrell 2004). Nimitän tutkimuksessani opiskelun tekstitaidoiksi taitoja, jotka ovat keskeisiä eri oppiaineissa ja kouluasteilla pärjäämisen kannalta.

Lukion opetussuunnitelma nojaa sosiokulttuuriseen näkemykseen tekstitaidoista, jolloin tekstitaidot, kuten lukeminen ja kirjoittaminen, eivät näyttäydy vain mekaanisina ja kerran opittavina taitoina, vaan niiden ajatellaan kehittyvän läpi elämän ja olevan omanlaisiaan erilaisissa tilanteissa (New London Group 1996). Tästä syystä kaikissa oppiaineissa edellytetään kielitietoista opetusta eli kieli ja tekstit tulisi huomioida kiinteänä osana ajattelua ja uuden oppimista (LOPS 2015: 38).

Väitöstutkimukseni tavoite on kuvata lukiolaisten koevastauksena kirjoittamaa aineistopohjaista esseetä, jotta historian opiskelua ja opetusta voitaisiin kehittää paremmin vastaamaan opetussuunnitelman tavoitteita. Näkökulmani esseiden tarkasteluun on tiedonalan tekstitaidoissa. Käsitteen avulla korostetaan sitä, että tiedonalayhteisöjen - kuten historian tai biologian - erilaiset tavat muodostaa tietoa heijastuvat myös eri oppiaineiden opiskeluun ja kieleen (Moje, Stockdill, Kim \& Kim 2011).

Tutkimukseni aiheen pariin minut johdatti kiinnostus opiskelun tekstilajeja ja ennen kaikkea eri oppiaineissa kirjoittamista kohtaan, sillä aiheesta on Suomessa vielä hyvin vähän tutkimusta. Erityisesti minua kiehtoi kysymys siitä, kuinka lukiossa voisi vielä paremmin opettaa kriittistä ajattelua ja asioiden tarkastelua monelta kantilta eli 
pohtivaa kirjoittamisen tapaa. Esseevastauksissa nämä vaatimukset yhdistyvät. Aihepiirin tutkimuksen tarpeesta kieli myös se, että keskeisyydestään huolimatta opiskelun esseetä on pidetty hankalasti määriteltävänä tekstilajina (Makkonen-Craig 2010: 219).

Tutkimukseni on tehty osana Koneen Säätiön ja Suomen Akatemian rahoittamaa, Hislit-nimellä kulkevaa monitieteistä hanketta, jossa tarkastellaan historian tiedonalan tekstitaitoja useasta näkökulmasta. Suomessa historian opetuksen lähtökohtana tulisi olla se, millainen historia on tiedonalana (LOPS 2015: 170). Historia eroaa tiedonmuodostukseltaan ainakin joiltain osin esimerkiksi luonnontieteistä: lukion biologian tai fysiikan opetussuunnitelmassa tiedontulkinnan lähtökohtana ovat ympäristöstä tehdyt havainnot ja kokeellisuus (LOPS 2015: 140, 152). Lukio-opiskelussa olisi oleellista ymmärtää, että historia ei kuvaa menneisyyttä sellaisenaan, vaan aina jossakin tietyssä ajassa muodostetun näkemyksen läpi (Wineburg 1991; Kalela 200o). Menneisyyden kuvaukset voivat siis vaihdella paljolti sen mukaan, kuka tulkintoja tekee, missä ajassa ja minkälaisin päämäärin. Historian tiedonmuodostuksen piirteiden vuoksi historian tapahtumien ja sisältöjen opiskelun tulisi kietoutua osaksi historian taitojen, kuten lähteiden tulkitsemisen, opettelua. (Rantala \& Ahonen 2015.)

Päätutkimuskysymykseni kuuluu, millainen on historian aineistopohjaisen esseen tekstilaji tiedonalalähtöisen historianopetuksen näkökulmasta. Tutkimukseni aineistona minulla oli 52 aineistopohjaista historian kurssikokeen esseevastausta, jotka oli kerätty Hislit-hankkeessa vuonna 2015. Tehtävänannossa opiskelijoilta kysyttiin, mitä dokumenttien perusteella voidaan päätellä kylmän sodan aloittajasta. Lähdemateriaaliksi annettiin neljä erityyppistä dokumenttia kylmän sodan alkuajoilta.

Menetelmällisesti tutkimukseni on laadullista tekstintutkimusta, jossa hyödynnän erikoiskielten tutkimusperinteen mukaista tekstilajianalyysia (Swales 1990) sekä systeemis-funktionaalista kieliteoriaa (jatkossa SF-teoria, Halliday 1973, 1978). Tekstilajilla tarkoitetaan jossain määrin vakiintuneita tekstin muotoja, jotka niitä käyttävä yhteisö tunnistaa ja nimeää. Usein tekstilajin tunnistaa lyhyellä vilkaisulla juuri tekstilajien vakiintuneisuuden takia, vaikka tekstilajit voivat myös limittyä, sekoittua ja muuttua (Mäntynen \& Shore 2014). Tekstilajien kielellisten piirteiden kuvaus auttaa ymmärtämään ihmisten kielenkäyttöä ja toimintaa erilaisissa tilanteissa. Analysoimalla historian esseen tekstilajia tuotan siis tietoa siitä, mitä kaikkea essee koevastauksen muotona edellyttää ja mahdollistaa osana historian opiskelua.

Väitöstutkimuksessani tarkastelen historian esseen tekstilajia neljästä näkökulmasta neljässä osatutkimuksessa, joissa kuvaan esseiden funktionaalista rakennetta (Paldanius 2017), historiallisen toiminnan esittämisen tapoja (Paldanius 2018), aineistojen käyttöä esseissä (Paldanius 2019) sekä pohdintaa rakentavia kirjoittajaääniä (Paldanius 2020). Esseiden rakenteeseen keskittyvässä artikkelissani analysoin erikoiskielten tutkimusperinteeseen nojaavan tekstilajiteorian avulla, millaiset tekstin osat eli siirrot ja askelet toteuttavat esseen viestinnällistä tehtävää. Kolmessa muussa osatutkimuksessani teoreettinen painotus on SF-teoriassa.

SF-teoria kuvaa kieltä nimensä mukaisesti yhtä aikaa järjestelmänä ja kielenkäyttönä, jotka vaikuttavat toinen toisiinsa. Kielellä voidaan välittää samanaikaisesti monenlaisia merkityksiä, joita tarkastellaan ja selitetään aina suhteessa kielenkäyttötilanteeseen eli tilanne- ja kulttuurikontekstiin (Halliday 2014 [1985]: 33). Kielen 
merkitystasot jaotellaan teoriassa niin sanottuihin metafunktioihin: ideationaalinen metafunktio keskittyy tekstin sisältöön, interpersoonainen vuorovaikutukseen ja tekstuaalinen siihen, miten teksti muodostuu tekstiksi. Näitä metafunktioita vastaavat tilannekontekstin tasolla kolme muuttujaa, jotka ovat ala (field), osallistujaroolit (tenor) ja ilmenemismuoto (mode). (Halliday 1973: 105-107.)

Historialliseen toimijuuteen keskittyvässä artikkelissa (Paldanius 2018) analysoin esseiden ideationaalisia merkityksiä prosessityyppianalyysin avulla. Analysoin lauseita sen kannalta, kuka tai mikä niissä esitetään toimijana ja minkälaista toimintaa tekstissä kuvataan. Aineistojen hyödyntämiseen ja pohdintaan keskittyvissä artikkeleissa taas analysoin interpersonaalisia merkityksiä hieman eri näkökulmista: Ensimmäisessä keskityn projektioihin ja analysoin sitä, millä tavoin esseiden lähteenä olevia historiallisia dokumentteja tuodaan osaksi vastausta (Paldanius 2019). Jälkimmäisessä taas analysoin esseiden lopetuksiin muodostuvia kirjoittajaääniä, jolloin sain näkyviin erilaisia tapoja esittää suhtautumista tietoon (Paldanius 2020).

Tutkimukseni tarjoaa aikaisempaa tarkemman kuvauksen siitä, millaisista kielen piirteistä aineistopohjainen ja pohtiva historian esseevastaus muodostuu. Esitän, että osa piirteistä yhdistyy historian tiedonalaan, osa taas esseen kirjoittamisen muihin tilannekontekstin piirteisiin. Esseen kokonaisuus muodostuu monenlaisista viestinnällisistä rakenneosista eli siirroista, jotka eroavat tehtäviltään ja kielellisiltä piirteiltään. Tyypillisesti esseen alussa esitellään aihe ja määritellään käsitteet kontekstualisoinniksi nimittämässäni siirrossa. Sen jälkeen kutakin dokumenttia käsitellään dokumentin erittely -siirrossa ja lopussa otetaan kantaa siirrossa, jota nimitän vastaus tehtävänantoon -siirroksi. (Paldanius 2017.)

Toimijuuteen keskittyvä artikkelini osoittaa, että esseissä on piirteitä historian tiedonalan tavoista esittää tietoa. Niissä hyödynnetään historian käsitteitä, kuten patoamispolitiikka ja kauhun tasapaino. (Paldanius 2018.) Historian kielelle on tyypillistä myös se, että valtiot toimivat kuin ihmiset ja voivat esimerkiksi sallia ja pakottaa. Havaintoni esseiden kielen ja historian tiedonalan kielen yhteneväisyyksistä tukevat ajatusta siitä, että kirjoitustaito ei ole kaikilta osin yleisesti sovellettavissa tilanteesta toiseen. Toisaalta esseiden ideationaalisiin piirteisiin heijastuu historian tiedonalan lisäksi muitakin tilannekontekstin piirteitä: tekstissä näkyy muun muassa oppikirjojen ja tieteellisen kielen abstrakti ja asioita toisiinsa suhteuttava esitystapa (esim. Karvonen 1995). Esimerkiksi seuraavassa lauseessa toimintaa kuvataan substantiivilla eikä lauseessa ole selvää toimijaa: ydinasevarustelu oli osa kylmää sotaa. Painopiste siirtyy toiminnasta eli varustelusta tapahtuman erittelyyn ja käsitteiden suhteuttamiseen.

Tutkimukseni keskeinen anti on kuvaus siitä, millainen on useamman dokumentin pohjalta kirjoitettu opiskelijan teksti. Esseiden aineistopohjaisuus näkyykin kaikissa osatutkimuksissa, ja aineiston käytössä on nähtävissä tiedonalakohtaisia piirteitä: esseissä ei kiinnitetä huomiota esimerkiksi siihen, millaisia retorisia keinoja dokumenteissa on käytetty, vaan analyysi ja päätelmät keskittyvät historian tapahtumiin. Projektiota tarkastelevassa artikkelissani kuvaan, kuinka erilaiset rekontekstualisoinnin tavat (ks. Linell 1998) eli tavat tuoda dokumentin sisältöä osaksi opiskelijan tekstiä muodostavat jatkumon dokumenttia suoraan toistavasta esityksestä sitä muuntelevaksi esitykseksi. Esimerkiksi projektio Churchill kertoo kehystää esityksen selostavammaksi kuin 
tulkintaa implikoiva projektio Churchillin puheessa käy selväksi. Projektio-artikkelini perusteella jo pelkkä dokumentin toistaminen sellaisenaan vaatii opiskelijalta tarkkuutta ja hyviä kirjoitustaitoja.

Esseevastauksia arvioiville opettajille lienee tuttua, että kirjoittajan oman äänen esiintuominen ja tekstilajilta vaadittava pohdinta ovat monille opiskelijoille hankalia asioita. Tutkimukseni esittää Caroline Coffinin (2006) tutkimusta soveltaen keinon lähestyä suomalaisissa opiskelun teksteissä tyypillistä pohdintaa kahden suhtautumisen teorian kategorian, asennoitumisen ja sitoutumisen, risteämänä (Martin \& White 2005). Kirjoittajaääniin keskittyvässä artikkelissani havaitsin, että osassa esseitä kirjoittajan oman ajattelun esittäminen keskittyy moraaliseen arviointiin ja tunteiden ilmaukseen, kuten seuraavassa: Itse saan kylmästä sodasta sellaisen kuvan, että jos Neuvostoliitto ei olisi ollut niin jyrkkä asenteissaan muuta maailmaa kohtaan, oltaisiin totaalinen, pelottava ja uhkaava sota voitu välttää. Tällaista, tunteen ja sosiaalisen hyväksynnän arvioita hyödyntävää ääntä nimitän arvottajaksi. Historian vastaukseen ja mahdollisesti laajemminkin opiskelun esseeseen tuntuu paremmin sopivan analysoijan äänellä toteutuva pohdintatapa, jossa kirjoittaja arvioi asioiden merkittävyyttä ja esittää olevan asiastaan varma, muttei kuitenkaan ehdoton. Tutkimukseni perusteella yksi syy oman äänen esittämisen vaikeudelle voi olla se, että pohdinta yhdistyy argumentointiin, joka taas voi toteutua mielipidemäisenä tai asia-argumentointina; historian vastauksessa ei ole hyväksyttävää esittää mielipiteitä, vaan pohdinnan tulisi perustua tietoon historian tapahtumista.

Tutkimukseni perusteella tarkastelemani kaltaisen esseen kirjoittaminen edellyttää monista, keskenään erilaisista osista muodostuvan tekstin rakenteen hallintaa, historian kielen hallintaa, aineistojen selostamisen ja tulkinnan taitoja, pohdinnan esittämisen taitoa sekä tietysti näiden kaikkien yhdistämistä koherentiksi vastaustekstiksi. Vaikuttaisi siltä, että kirjoittajat ovat jo monin tavoin sosiaalistuneet opiskeluissa tärkeisiin kirjoittamisen taitoihin. Esseiden rakenteen jonkinasteinen mekaanisuus saattaa kuitenkin kieliä tehtävän haastavuudesta, ajan puutteesta ja tottumattomuudesta rakentaa vastaus usean aineiston pohjalta. Myös historian vastaukseen sopiva pohdinta vaatii kirjoittajalta harjaantumista siihen, millainen oman äänen esitystapa sopii eri oppiaineisiin ja erilaisiin tehtävänantoihin.

Esseen tekstilaji - samoin kuin historian opetuksen tavoitteet - edellyttävät opiskelijalta tiedon tulkintaa, arviointia ja soveltamista, jotka ovat pelkkään tiedon toistamiseen verrattuna vaikeampia tiedonkäsittelytapoja. Edistyneimmät kirjoittajat hallitsevat tällaisen tiedon prosessoinnin, mutta monet tarvitsevat paljon apua kehittyäkseen tiedon toistajasta tiedon tulkitsijaksi. Harjaantumista näihin taitoihin ei pitäisi jättää opiskelijan harteille. Yksi apu tiedonalalähtöiseen kirjoittamisen opetukseen voisi löytyä genrepedagogiikasta, jossa lähtökohtana on opiskelijoiden ja opettajien ymmärrys tekstilajien eroista ja keskeisistä ominaisuuksista. Tekstilajien taju ja kirjoitustaito kehittyvät, kun saa ohjausta, pääsee vertailemaan tekstejä ja oppimaan palautteesta. (Ks. esim. Luukka 2004.)

Historian opetuksen tavoitteisiin kuuluu, että historian tietoja ja taitoja ei nähdä erillisinä. Taitopainotteisessa opetuksessa historian sisältöjä tulisi siis opettaa siten, että tekstikäytänteet ja tekstitilanteet mahdollistavat esimerkiksi aineistojen tulkinnan har- 
joittelun. Tutkimukseni herättääkin kysymyksen siitä, kuinka hyvin perinteisessä koetilanteessa kirjoitettu essee soveltuu historian opetuksen tavoitteiden mukaiseen opiskeluun. Kirjoitusaika on lyhyt eikä tietoa ole mahdollista hakea lisää, jolloin tutkiva ja tietoa kyseenalastava, analysoiva ja tulkitseva kirjoittaminen voivat helposti kutistua opitun tiedon toistamiseen (tutkivasta historian opiskelusta ks. Veijola, Sulkunen \& Rautiainen 2019). Esseen tekstilajin hallitseminen on kuitenkin tärkeää, sillä se harjaannuttaa muun muassa pitkän asiatekstin laatimiseen sekä aineistojen lukemiseen ja tulkitsemiseen eli niihin opiskelun tekstitaitoihin, joita tarvitaan eri oppiaineissa kirjoittamisessa ja siten opintopolulla pärjäämisessä.

Suomessa ei ole vielä kovin vahvaa opiskelun tekstilajien ja tiedonalan tekstitaitojen tutkimusperinnettä. Tutkimukseni onkin avaus kohti sitä, että kirjoitustaitojen tärkeys osana kaikkien oppiaineiden opetusta saadaan näkyvämmäksi. Oppiaineiden hallintaa arvioidaan usein kirjoittamisen pohjalta, ja sitä mitä arvioidaan, pitäisi luonnollisesti myös opettaa. Erityisen tärkeää tämä on niiden opiskelijoiden kohdalla, jotka eivät tuosta vain ota haltuun esseen kaltaista, kompleksista tekstilajia.

\section{Lähteet}

Coffin, Caroline 2006. Historical discourse. The language of time, cause and evaluation. London: Continuum.

Halliday, M. A. K. 1973: Explorations in the functions of language. London: Arnold.

2014 [1985]: An introduction to functional grammar. Uudistettu yhdessä M. I. M. Matthiessenin kanssa. London: Arnold.

Kalela, Jorma 200o: Historiantutkimus ja historia. Helsinki: Gaudeamus.

Karvonen, Pirjo 1995: Oppikirjateksti toimintana. Helsinki: Suomalaisen Kirjallisuuden Seuran toimituksia 632.

Linell, Per 1998: Discourse across boundaries. On recontextualizations and the blending of voices in professional discourse. - Text 24 s. 143-157. https://doi.org/10.1515/ text.1.1998.18.2.143.

LOPS $2015=$ Lukion opetussuunnitelman perusteet 2015. Opetushallitus.

LuUkKa, Minna-Riıt Ta 2004: Genre-pedagogiikka: askelia tekstitaitojen jatkumolla. Minna-Riitta Luukka \& Pasi Jääskeläinen (toim.), Hiiden hirveä hiihtämässä. Hirveä(n) ihana kirjoittamisen opetus. Äidinkielen opettajain liiton vuosikirja 2004 s. 145-16o. Helsinki: Äidinkielen opettajain liitto.

Makkonen-Craig, Henna 2010: Ylioppilasaine ja päättökokeen tavoitediskurssi. Genre ja varjogenre. - Hanna Lappalainen, Marja-Lenna Sorjonen \& Maria Vilkuna (toim.), Kielellä on merkitystä. Näkökulmia kielipolitiikkaan s. 206-252. Suomalaisen Kirjallisuuden Seura.

Martin, J. R. - White, P. R. R. 2005: The language of evaluation. Appraisal in English. New York: Palgrave MacMillan.

Moje, E. - Stockdill, D. - Kim, K. - Kim, H. 2011: The role of text in disciplinary learning. - Michael Kamil, David Pearson, Elizabeth Moje \& Peter Afflerbach (toim.), Handbook of reading research. Volume IV s. 453-486. New York: Routledge.

Mäntynen, Anne - Shore, Susanna 2014: What is meant by hybridity? An investigation of hybridity and related terms in genre studies. Text \& Talk 34 s. 737-758. https://doi. org/10.1515/text-2014-0022. 
New London Group 1996: A pedagogy of multiliteracies. Designing social futures. -Harvard Educational Review 66, s. 60-92. https://doi.org/10.17763/haer.66.1.1737on67v22j16ou.

Paldanius, Hilkka 2017: Historian esseevastauksen funktionaalinen rakenne. - Sirkku Latomaa, Emilia Luukka, \& Nina Lilja (toim.), Kielitietoisuus eriarvoistuvassa yhteiskunnassa. Language awareness in an increasingly unequal society. AFinLAn vuosikirja 2017 s. 219-238. Jyväskylä: Suomen soveltavan kielitieteen yhdistys AFinLA.

— 2018: Historiallisen toimijuuden rakentuminen lukiolaisten esseevastauksissa. - Virittäjä 112 s. 53-78. https://doi.org/10.23982/vir.59310.

2019: Selostuksesta tulkintoihin. Aineistojen esittäminen lukiolaisten historian esseissä. - Virittäjä 123 s. 347-372. https://doi.org/10.23982/vir.70430.

2020: Kuinka pohtivuutta edellyttävään tehtävänantoon vastataan? Erilaiset kirjoittajaäänet lukiolaisten historian esseissä. - Kasvatus \& Aika 14 (2) s. 35-56.

Rantala, Jukka - Ahonen, Sirkka 2015: Ajan merkit. Historian käyttö ja opetus. Helsinki: Gaudeamus.

SChLEPPEgRLL, MARY 2004: The language of schooling. A functional linguistic perspective. New York: Routledge.

Swales, John 1990: Genre analysis. English in academic and research settings. Cambridge: Cambridge University Press.

Veijola, Anna - Sulkunen, Sari - Rautiainen, Matti 2019: Historiallisen tiedon luonne ja historian tekstikäytänteet lukiolasten kuvaamana. - Kasvatus \& Aika 13 (2) s. 53-67.

WINEBURG, SAM 1991: Historical problem solving. A study of the cognitive processes used in the evaluation of documentary and pictorial evidence. - Journal of Education Psychology 83 s. 73-87. https://doi.org/10.1037/0022-0663.83.1.73.

Hilkka Paldanius: Kuka aloitti kylmän sodan? Lukion historian aineistopohjaisen esseen tekstilaji tiedonalan tekstitaitojen näkökulmasta. Jyväskylä Studies in Humanities 227. Jyväskylä: Jyväskylän yliopisto. Väitöskirja on luettavissa osoitteessa: https://jyx.jyu.fi/ handle/123456789/70172.

Kirjoittajan yhteystiedot:

etunimi.sukunimi@gmail.com 